\title{
Joseph Sax and the Idea of the Public Trust
}

\author{
Carol M. Rose*
}

"Public trust": what an arresting phrase. Perhaps it is not quite the equal of "the tragedy of the commons,"1 but it catches the attention in a far more positive way, with its intimations of guardianship, responsibility, and community. My task here is to show how Joseph Sax deployed this evocative phrase, and expanded the concepts behind it, to challenge our ideas about natural resource management. For reasons that I hope will become clear, I find that I cannot deal with this task independently of the other topics on the panel-public lands policy to some degree, the takings question to a greater degree, but most of all water law, where the public trust is, if I may use the phrase, deeply immersed.

First, what is the public trust as a legal matter? Until it was revived and re-invented by Sax, the doctrine held that some resources, particularly lands beneath navigable waters or washed by the tides, are either inherently the property of the public at large, or are at least subject to a kind of inherent easement for certain public purposes. ${ }^{2}$ Those purposes are foremost navigation and travel, to a lesser extent fishing, and lesser still recreation and public gatherings. ${ }^{3}$ This set of notions first appeared in Roman law and has floated through English and now American law. ${ }^{4}$ In England, the public trust doctrine bobbed up in some of the seventeenth century debates over royal prerogative $;^{5}$ it made another appearance in some American tidelands cases

Copyright (C) 1998 by Ecology LAw QuARTERLY

* Gordon Bradford Tweedy Professor, Yale Law School.

1. See Garrett Hardin, The Tragedy of the Commons, 162 SCIENCE 1243 (1968).

2. See Patrick Deveney, Title, Jus Publicum, and the Public Trust: An Historical Analysis, 1 Sea Grant L.J. 12, 14 (1976).

3. See id.; Note, The Public Trust in Tidal Areas: A Sometime Submerged Traditional Doctrine, 79 YAlE L.J. 762, 763-64 (1970); Jan S. Stevens, The Public Trust: A Sovereign's Ancient Prerogative Becomes the People's Environmental Right, 14 U.C. DAVIS L. Rev. 195, 222 (1980). See also Carol M. Rose, The Comedy of the Commons: Custom, Commerce, and Inherently Public Property, 53 U. CHI. L. REv. 711, 778 (1986) (for the extension of a version of the "trust" to public meeting spaces-"public forums").

4. See Rose, Commedy of the Commons, supra note 3, at 727-30 (for a capsule history).

5. See Glenn J. MacGrady, The Navigability Concept in the Civil and Common Law, 3 Fla. St. L. Rev. 511, 559-62 (1975). 
before the Civil War; 6 and it got a major boost from the Supreme Court in 1892 in Illinois Central Railroad v. Illinois. ${ }^{7}$ For a few decades after Illinois Central, a flurry of state waterway cases used the concept. In later decades these public trust cases subsided, though they never entirely vanished. ${ }^{8}$

Joseph Sax's 1970 article, The Public Trust Doctrine in Natural Resources $L a w^{9}$, ushered in the next and most recent major revival of the public trust concept. Sax returned to the old but persistent legal idea-that at least some resources or properties are especially subject to public claims-but unhooked it from its traditional moorings on or around water bodies and applied it to dry land as well. He himself has referred to the concept of the pubic trust in his discussions of the takings doctrine, ${ }^{10}$ historical and cultural resources, ${ }^{11}$ and a variety of ecological resources. ${ }^{12}$ More than that, simply by dusting off this venerable phrase, Sax's Public Trust Doctrine article added a powerful, if controversial, rhetorical element to the discussion of these resource areas.

One way to understand Sax's version of the public trust is to think back to the time that Sax wrote the article. Published in 1970, the Public Trust Doctrine appeared between two major articles that Sax wrote on the subject of takings-one published in $1964^{13}$ and the

6. See, e.g., Martin v. Waddell, 41 U.S. 367, 410 (1842); Arnold v. Mundy, 6 N.J.L. 1, 71-78 (N.J. 1821).

7. 146 U.S. 387 (1892) (negating the privatization of the Chicago waterfront).

8. Sax, for example, used post-Illinois Central cases from Wisconsin and California in his seminal article, Joseph L. Sax, The Public Trust Doctrine in Natural Resources Law: Effective Judicial Intervention, 68 Mich L. Rev. 471, 509-46 (1970) [hereinafter Sax, The Public Trust Doctrine]. For developments in Florida, see Michael L. Rosen, Public and Private Ownership Rights in Lands Under Navigable Waters: The GovernmentalProprietary Distinction, 34 U. FLA. L. REv. 561, 588-610 (1982).

9. See Sax, The Public Trust, supra note 8.

10. See Joseph L. Sax, Takings, Private Property and Public Rights, 81 Yale L.J. 149, 155, 155 n.16, 171 (1971) [hereinafter Sax, Takings, Private Property].

11. See Joseph L. Sax, Is Anyone Minding Stonehenge? The Origins of Cultural Property Protection in England, 78 CAL. L. Rev. 1543, 1558 (1990).

12. Contemporaneously with his Michigan article, Sax made a quite expansive statement of the trust's reach in popular form in the chapter The Public Trust: A New Charter of Environmental Rights, in Joseph L. SAx, Defending The ENvironment 158, 172 (1971) (describing trust as applicable to air, water, congestion, noise, natural areas, pesticides, radioactivity and environmental problems generally). See also Joseph L. Sax, The Constitution, Property Rights and the Future of Water Law, 61 U. CoLo. L. REv. 257, 26970 (1990) (mentioning use of public trust to protect fisheries and riparian ecosystems); Joseph L. Sax, The Search for Environmental Rights, 6 J. LAND UsE \& ENVTL. L. 93, 105 (1990) (arguing that private ownership in "natural endowment of water, soil, and air ... should be considered subordinate to the public trust obligation" to maintain genetic stock, biodiversity, and undiminished productive capacity).

13. Joseph L. Sax, Takings and the Police Power, 74 YALE L.J. 36 (1964) [hereinafter Sax, Police Power]. 
other in 1971.14 In his 1964 article, Takings and the Police Power, Sax posited a "good guy/bad guy" view of governmental regulation. In the good guy regulation, government acted in an "arbitrage" mode, settling disputes among more or less equally situated property owners. In the bad guy scenario, government acted in an "enterprise" mode, regulating in order to press private individuals' property into public service. ${ }^{15}$ In some ways, this analysis recalled an older view of regulation, distinguishing [good] nuisance-preventing regulation from [bad] public-benefit-providing regulation ${ }^{16}$ - an analysis that has never been precisely delineated, but that has always had a residuum of common sense appeal. ${ }^{17}$ It is essentially an analysis of takings that reflects a concern about majority over-reaching at the expense of minority rights.

But by the time of his second takings article in 1971, Takings, Private Property and Public Rights, Sax was much more impressed by the fragility of majority governance and the corresponding need to bolster majority rule to solve environmental problems. It was this set of concerns that appeared not only in the second takings articlewhere Sax found more latitude for governmental action vis-a-vis private property ${ }^{18}$ - but also in the Public Trust Doctrine article. What accounted for the difference in the intervening decade? One set of factors was pragmatic: the later years of the 1960s saw the beginnings of modern environmentalism. As he was working on the public trust article, Sax himself was also heavily engaged in developing a state environmental protection act for the state of Michigan. ${ }^{19}$

Just as important were intellectual factors: the decade also saw important shifts in theories of government. A new "public choice" analysis argued that sharply focused minority interests could often get their way in legislatures at the expense of diffuse majorities ${ }^{20}$ - and

14. Sax, Takings, Private Property, supra note 10.

15. See Sax, Police Power, supra note 13, at 62-64 (distinguishing arbitrage and enterprise roles).

16. See Ernst Freund, The Police Power 546-47 (1904).

17. See, e.g., Robert C. Ellickson, Alternatives to Zoning: Covenants, Nuisance Rules, and Fines as Land Use Controls, 40 U. CHI. L. REv. 681, 728-33 (1973) (basing compensation vel non on the ordinary understanding of nuisance-like or "subnormal" character of the activity regulated).

18. See Thomas W. Merrill, Compensation and the Interconnectedness of Property, 25 ECOLOGY L. Q. 327.

19. Sax described some of the results in Joseph L. Sax \& Joseph F. DiMento, Environmental Citizen Suits: Three Years' Experience Under the Michigan Environmental Protection Act, 4 Ecology L.Q. 1 (1974); Joseph L. Sax \& Roger L. Conner, Michigan's Environmental Protection Act of 1970: A Progress Report, 70 Mich. L. Rev. 1003 (1972).

20. Among the important early works were JAMEs M. Buchanan \& Gordon TuLlock, The Calculus of Consent (1962) and Mancur Olson, The Logic of CollecTIVE ACTION (1965). For a perspective on Olson's work in particular, see Daniel A. Farber, Positive Theory as Normative Critique, 68 S. CAL. L. Rev. 1565 (1995). For the 
what could be more diffuse than environmental concerns? Meanwhile, in the administrative arena, "capture" theorists described the similar ways that regulated interests could take over the very public agencies that supposedly regulated them. Significantly, Phillip Foss's Politics and Grass, ${ }^{21}$ a seminal book for capture theory, was published at the beginning of the decade. This book described the takeover of federal grazing councils by local grazing interests and had considerable influence on environmentalists interested in the management of the public lands.

All of these factors combined to suggest that in environmental matters the most serious problem was not overbearing majoritarianism, but rather the weakness and incompetence of majority rule vis-avis focused minority interests. With respect to the environment, majority government needed not just more managerial authority, but better informed and more flexible management to empower it against private stakeholders' importuning. In an effort to address this dilemma, Sax drew upon the property area in which he developed an early expertise: water law. ${ }^{22}$

Water law in general is a fount of doctrine for public resource management, since water is indeed a diffuse resource with a long history of community management. As Sax has stressed in subsequent years, water rights have always had some elements of communal management and responsiveness to change "built in," as it were. ${ }^{23}$ Unlike land, water's development, use, and transfer unambiguously implicate many other users and types of use, and thus the legal regimes for water rights have tended to evolve in such ways as to incorporate greater concern for diversity and changes in use. Historically, the public trust doctrine has been only a small part of water law, but Sax's discussions often seem to have in mind not so much the fairly specific doctrine of public trust as the larger picture of water law, with its long history of public management and readjustments. ${ }^{24}$

influence of this literature on Sax's work on the takings doctrine, see generally Merrill, supra note 18.

21. Phillip O. Foss, Politics and Grass (1960).

22. By the time of the public trust article, Sax had published his casebook, WATER Law, Planning and Policy: Cases and Materials (1968) [hereinafter Sax, Water LaW, Planning and Policy]. For an even earlier typescript volume, see Joseph L. SaX, Water law: Cases and Commentary (1965).

23. See Joseph L. Sax, Rights that "Inhere in the Title Itself": The Impact of the Lucas Case on Western Water Law, 26 Loy. L.A. L. Rev. 943, 944, 950-51 (1993) (Water law delineates rights as subject to public constraints and changing circumstances.); Joseph L. Sax, The Limits of Private Rights in Public Waters, 19 EnvTL. L. 473, 482 (1989) (Water rights are always subject to public limits and change.).

24. When Sax has cited the public trust doctrine, he has often done so in the context of other water law principles. See, e.g., supra note 12 and sources cited therein. 
Just as Sax has often generalized the flexibility of water law principles, so too has he generalized the concept of the public trust, using this vivid phrase as a vehicle for insisting that public bodies pay attention to-and adequately vindicate-the changing public interest in diffuse resources. In particular, in his 1970 Public Trust Doctrine article, Sax effectively treated the public trust as a common-law version of the then-novel "hard look" doctrine for environmental impacts. According to Sax's analysis, the public trust doctrine required the collection of adequate information, public participation in decisions, informed and accountable choices, and close scrutiny of private giveaways of environmental resources. ${ }^{25}$

Nine years later, Sax seemed to change focus when he described the task as one of "liberating" the trust from its "historical shackles." There, he argued that the public trust should become a tool for avoiding destabilizing change and for incorporating community values in decisions about social as well as ecological resources. ${ }^{26}$ Despite the apparent differences in these depictions of the trust, however, they may be closer than they seem: in subsequent years, we have learned how the "hard look" doctrine can be used by community groups to delay change. These two versions of the trust, taken together, suggest that Sax's goal was to loosen the public trust doctrine from its historical connection with navigation and waterways, and turn the doctrine instead into a more general device for managing change and recognizing community values in diffuse resources.

While other authors diverged in a number of ways from Sax's vision of the public trust, many followed his lead in generalizing the concept beyond its historic confines, using the idea of the public trust to discuss not only traditional waterways, but also upland beaches, ${ }^{27}$ water policy more generally, ${ }^{28}$ public lands management, ${ }^{29}$ wildlife, ${ }^{30}$ ecological resources in general, ${ }^{31}$ and of course the takings issue. ${ }^{32}$

Sax's revival and expansion of the public trust doctrine, however, was not without its critics. Though the general concept, and Sax's arti-

25. See Sax, The Public Trust Doctrine, supra note 8, at 557-65.

26. See Joseph L. Sax, Liberating the Public Trust Doctrine from Its Historical Shackles, 14 U.C. Davis L. Rev. 185 (1980).

27. See, e.g., Stevens, supra note 3 (applying public trust doctrine to beaches).

28. See, e.g., Symposium on the Public Trust and the Waters of the American West, 19 ENVTL. L. 1 (1989).

29. See, e.g., Charles F. Wilkinson, The Public Trust Doctrine in Public Land Law, 14 U.C. Davis L. Rev. 269 (1980) (attempting to use public trust as source of public land law).

30. See, e.g., Gary D. Meyers, Variation on a Theme: Expanding the Public Trust Doctrine to Include Protection of Wildlife, 19 ENVTL. L. 723 (1989).

31. See, e.g., Alison Rieser, Ecological Preservation as a Public Property Right: An Emerging Doctrine in Search of a Theory, 15 HARv. ENvTL. L. REv. 393 (1991).

32. See, e.g., Stevens, supra note 3 (using public trust for public claims over beach). 
cle in particular, were widely cited in cases and subsequent scholarship, the doctrine itself remained vague. ${ }^{33}$ Was it a substantive doctrine about resources with particular public elements? If so, how was one to distinguish "public trust" resources from others? Or was it a procedural theory of governance, and if so, to which subjects did its enhanced theories apply ${ }^{34}$ Was it, as even some environmentalist critics suggested, a misguided effort to dredge up ancient flotsam in a way that obscures contemporary environmental issues instead of illuminating them?35 Or finally, as some property rights proponents argued, was the verbiage about the "public trust" merely a rhetorical shield for still further public depredations on private property ${ }^{36}$

Perhaps less obvious than some of the other nagging issues about the public trust-but no less central-was a question that echoed a nineteenth century concern about the doctrine: was the public trust in some sense property? That is, do resources impressed with the public trust in some sense belong to the public in such a way that the public's property claims override the acts of its own agents, even the legislature? In the nineteenth century, this issue was framed in terms of the alienability of public trust property, and it was quite hotly debated. New Jersey courts represented one view, declaring that the public trust was indeed the public's property, inalienable even through legislative acts. New York courts took the opposite position-altered only after the 1892 Illinois Central case seemed to support the New Jersey view-that the legislature was the sovereign representative of the public at large, and as such could act in the public's name, even to alienate trust property. ${ }^{37}$

33. See Rose, Comedy of the Commons, supra note 3 , at 722 (describing vagueness of cases' and articles' descriptions of public trust).

34. The public trust as a doctrine for promoting representative government is explored-but ultimately rejected-in William D. Araiza, Democracy, Distrust and the Public Trust: Process-Based Constitutional Theory, the Public Trust Doctrine and the Search for a Substantive Environmental Value, 45 UCLA L. Rev. 385, 413-33 (1997). See also A. Dan Tarlock, Book Review, 47 IND. L.J. 406, 412 (1972) (reviewing JosEPH L. SAX, Defending THE ENVIRONMENT (1971)) ("The public trust theory, which expresses one simple idea, is not a general theory of resource allocation.").

35. See, e.g., Steven M. Jawetz, The Public Trust Totem in Public Land Law: Ineffective-And Undesirable-Judicial Intervention, 10 Ecology L.Q. 455, 467-70, 487-88 (1982) (arguing that the public trust concept is not useful with respect to public lands, does not give needed specific guidance to courts, and that specific statutes are preferable); Richard J. Lazarus, Changing Conceptions of Property and Sovereignty in Natural Resources: Questioning the Public Trust Doctrine, 71 Iowa L. Rev. 631, 715-16 (1986) (public trust doctrine a "step backward toward a bygone era").

36. See, e.g., James L. Huffman, A Fish Out of Water: The Public Trust Doctrine in a Constitutional Democracy, 19 ENvTL. L. 527 (1989) (arguing that the public trust doctrine is an effort to evade just compensation).

37. See Rose, Commedy of the Commons, supra note 3, at 735-39 (describing different views). 
In his 1970 Public Trust Doctrine article, Sax took the early New York position: he refused to treat the public trust doctrine as conferring property rights on the general public as distinct from the legislature. ${ }^{38}$ There were good reasons for this, both as a general matter and for Sax's purposes in particular. First, a trust-based public property right would mean that the unorganized public could trump its own legislature's acts, implying that the public trust was some sort of an informal constitutional right, something certainly outside normal American legal practice. But for Sax, a second reason may have been more important: he was most urgently concerned with extending and improving the public management of diffuse environmental resources.

Looking toward that end, Sax evidently thought that a "property" framework for the public trust would act as a constraint on legislatures where expansion was required, and would add a note of rigidity where flexibility was warranted. Hence Sax was willing to leave ultimate control of the public trust in legislative hands, since ultimately the public can only successfully manage the complex issues of environmental protection through its representatives.

Other scholars, however, have argued that Sax's use of the public trust did establish some sort of property rights in the public at large, however much Sax may have bridled at the idea. ${ }^{39}$ Subsequent versions of the public trust, incorporating the property notion of the doctrine, have taken directions with interesting parallels to and divergences from Sax's original concern with managing change and involving the public in decisionmaking over diffuse environmental resources. I describe here three such scholarly directions, not chronologically, but in an order that elucidates some of the salient features of Sax's original ideas.

Richard Epstein seems to have picked up on the "property" notion of the public trust precisely for the reasons that made Sax nervous: in its property incarnation, the public trust doctrine does imply constraints on legislatures. Epstein has likened the public trust doctrine to the takings doctrine that protects private property. Both doctrines, he argues, represent the idea that property puts bounds on legislatures, preventing them from colluding with the various "rentseekers" who attempt to use the political process to redistribute the wealth of others to themselves. ${ }^{40}$ If the public trust represents prop-

38. See Sax, The Public Trust Doctrine, supra note 8, at 478-84.

39. See, e.g., Julian C. Juergensmeyer \& James B. Wadley, The Common Lands Concept: $A$ "Commons" Solution to a Common Environmental Problem, 14 NAT. ResourCes J. 361, 377-79 (1974) (arguing that Sax's position implies a property right in the public); Daniel R. Coquillette, Muses from an Old Manse: Another Look at Some Historic Property Cases about the Environment, 64 CORNELl L. REv. 761, 811-13 (1979) (criticizing Sax's argument against a public property view of the trust).

40. See Richard A. Epstein, The Public Trust Doctrine, 7 Cato J. 411, 418-21 (1987). 
erty belonging to the public, inalienable by their purported agents in the legislature (or alienable only under sharp restrictions), then Epstein argues that the doctrine's true function is to restrain legislators from giving away the store for private gain to the general detriment of the public at large. ${ }^{41}$ While the Epstein view seems remarkably "green" for him-representing the idea that the public can have property-he nevertheless has managed to massage the doctrine into a shape that fits his general antipathy to legislative politics and his willingness to find judicial remedies to control those politics. ${ }^{42}$

Interestingly, Epstein's anti rent-seeking cast on the public trust doctrine may have some historical verification, and may also accord with some of Sax's concerns. From quite different directions, Louise Halper and William Fischel, in their respective investigations of late nineteenth century nuisance law and eminent domain doctrine, have described how the courts drew distinctions in these doctrinal areas to rein in the most egregious legislative giveaways of the day, particularly those that benefitted railway companies. ${ }^{43}$ Certainly one could make a convincing argument that the Supreme Court's Illinois Central decision, the famous 1892 revival of the public trust doctrine in the context of a public giveaway to a railroad, sprang from much the same impulse. Indeed, control of rent-seeking is not far removed from at least a few of Sax's own desiderata for environmental management in 1971. The problem with this property version of the public trust, however, is that while it may serve the negative function of restraining legislative giveaways, it does little to empower public agencies or impel them towards responsible management. For Sax, that was not enough.

A second use of the property version of the public trust is as a governmental defense against takings claims. If the public trust doctrine means that the public owns an easement in trust lands, this argument goes, then private property within the trust area is purchased subject to trust uses, and private owners need not be compensated for regulations that maintain public trust purposes. A trace of this idea appeared in Just $v$. Marinette County, a Wisconsin case refusing to compensate an owner on his "takings" claim against wetlands protec-

41. Id.

42. For a discussion (and critique) of Epstein's jaundiced view of legislatures as particularly prone to rent-seeking and of his reliance on judicial control of legislatures, see Thomas W. Merrill, Rent-Seeking and the Compensation Principle, 80 Nw. U. L. Rev. 1561, 1583-90 (1987) (reviewing Richard A. Epstein, Takings: Private Property and the Power of EMINENT DOMAIN (1985)).

43. See William A. Fischel, Regulatory Takings: Law, Economics, and PoliTICs 88-94 (1995) (describing alterations in eminent domain law to broaden compensation to owners near urban railways); Louise A. Halper, Nuisance, Courts and Markets in the New York Court of Appeal, 1850-1915, 54 Alb. L. Rev. 301, 319-20, 328 (1990) (same in nuisance law). 
tion legislation. ${ }^{44}$ The view appeared again more forcefully in some other state cases disposing of private property claims against public regulation of waterfront areas. ${ }^{45}$ This use of the public trust as a takings defense, of course, has outraged property rights proponents. ${ }^{46} \mathrm{~A}$ 1995 proposed antitakings bill in Montana, for example, specifically referred to the public trust doctrine and would have nullified its use as a defense against takings claims. ${ }^{47}$

Interestingly, Sax was less certain about this defensive use of the trust idea in his 1968 casebook on water law, ${ }^{48}$ and he even anticipated an idea, later articulated by my co-panelist Buzz Thompson, that judicial decisions vindicating the public's "trust" rights might require compensation as takings from private owners. ${ }^{49}$ But in a sense, the use of the public trust as a takings defense is quite in line with Sax's desire to protect diffuse resources. As the analysis of public choice theory suggests, private property owners have very focused wishes for their property, and they may often out-shout the widely-but-shallowly-felt interests in, say, wetlands protection or endangered species preservation. The difficulty lies in the old question of definition: just what properties count as "impressed with a public trust" for purposes of takings defenses and why? Unfortunately, cases and commentators on the public trust have been uncomfortably vague about its reach. ${ }^{50}$

Still another take on the property version of the public trust is one that I have explored, though I must confess that rather few have followed suit. Several years ago, I looked at the doctrine historically and found that it was only one of several that supported the idea that some property inherently belongs to the public. ${ }^{51}$ The main thrust of these "inherent public property" doctrines, however, was not particularly aimed at preserving resources that we generally denote as environmental. Instead, the key feature of these doctrines was to reserve for the public those properties that the public needs for travel, communication, commerce, and to some degree public speaking - that is, uses that connect people with one another and with a wider world and

44. Just v. Marinette County, 201 N.W.2d 761 (Wis. 1972).

45. See, e.g., National Audubon Soc'y v. Superior Court, 658 P.2d 709 (Cal. 1983) (water), cert. denied, 464 U.S. 1065 (1983); City of Berkeley v. Superior Court, 606 P.2d 362 (Cal. 1980) (tidelands), cert. denied, 449 U.S. 840 (1980); Matthews v. Bay Head Improvement Ass'n, 471 A.2d 355 (N.J. 1984) (tidelands).

46. See, e.g., Huffman, supra note 36 (public trust an evasion of compensation duty).

47. See H.R. 597, 54th Leg., 1st Reg. Sess. § 3(8) (Mont. 1995) (this private property protection act was not enacted).

48. See Sax, Water Law, Planning and Policy, supra note 22, at 304.

49. Id.; See Barton H. Thompson, Jr., Judicial Takings, 76 VA. L. REV. 1449 (arguing that alterations in judicial doctrine may constitute takings).

50. See, e.g., Matthews, 471 A.2d at 365 (public trust is "flexible"); Sax, The Public Trust Doctrine, supra note 8, at 556-57; Wilkinson, supra note 29, at 315 (1980).

51. See Rose, Commedy of the Commons, supra note 3, at 711-14. 
allow all to interact in a social whole..$^{52}$ In this context, the public trust doctrine only indirectly relates to environmental resources-perhaps insofar as recreation, the experience of natural wonders, and the preservation of biodiversity act as a part of a liberal education, promote public health (including mental health), and generally enable people to interact with one another more productively and civilly. ${ }^{53}$ These environmental concerns are not inconsiderable matters, and they are certainly related to traditional public trust thinking. But it may be that much stronger modern echoes of the public trust doctrine can be heard elsewhere: in discussions of public claims to use communications media freely - notably the internet, where a current debate rages over the degree to which intellectual property should lock the doors on information transfer. ${ }^{54}$

Interestingly, it now appears that a rather different, older property doctrine might have more directly targeted Sax's environmental concerns. Indeed, it is a doctrine that Sax undoubtedly knew well, especially since, as I suggest above, he often seemed to use the language of the public trust doctrine when he actually had in mind more general water law concepts. The set of water law doctrines known as riparianism, though long dismissed as antiquated, may now be emerging as a particularly helpful model for ecological management.

The heyday of riparian law was the nineteenth century, in the early days of industrialization. The problem that this body of law addressed, briefly, was to assure that river water could drive watermills all the way down a river's length, while allowing watermills to consume some very modest amount of water due to millpond seepage and the like. ${ }^{55}$ Notice that this is the pattern typical of modern environmental problems: to preserve the bulk of a renewable resource, while permitting very modest uses at the fringes, as it were, compatible with the preservation of the whole. The riparian solution to this problem

52. See Id. at 770, 774-81.

53. Id. at 779-81.

54. See, e.g., Pamela Samuelson, The Copyright Grab, WIRed MAG., Jan. 1996, at 135 (decrying proposals to over-propertize materials on internet); see generally Carol M. Rose, The Several Futures of Property: Of Cyberspace and Folk Tales, Emission Trades and Ecosystems (forthcoming MINN. L. REv. 1998) (describing property/commons debate in cyberspace and environmental law).

55. See A. Dan Tarlock, Law of Water Rights and Resources (1988); Carol M. Rose, Riparian Rights, in 3 New Palgrave Dictionary of Economics and the Law 344 (Peter Newman, ed., 1998); Carol M. Rose, Energy and Efficiency in the Realignment of Common-Law Water Rights, 19 J. Legal STUd. 261, 290-93 (1990). See also A. Dan Tarlock, New Water Transfer Restrictions: The West Returns to Riparianism, 27 WATER Resources Research 987 (1991); A. Dan Tarlock, The Missouri River: The Paradox of Conflict Without Scarcity, 2 Great Plains Nat. Resources J. 1 (1997); A. Dan Tarlock, River Management in the Twenty-first Century: The Vision Thing, 6 Rivers 43 (1997) (arguing that the western states are imposing and should extend a new riparianism for aquatic ecosystem management). 
had several parts. First, it limited the use of river water to riverbank owners, prohibiting inter-basin transfer and thus effectively turning the river water into a property common to the bank owners while excluding all others. Second, within this group of water users, each was allocated a modest claim, limited to "reasonable use"-a minor use compatible with similar consumptive claims by all other users and with the untouched preservation of the bulk of the river resource. ${ }^{56}$

This was a judge-made solution to a complex problem of interactive uses of a renewable resource. It aimed at protecting industrial uses rather than environmental ones, and it was not notably helpful in dealing with issues of pollution or fisheries management. But in outline, riparian law included the basic structural features of modern environmental management: it capped the total permissible use of the river water at a level that allowed regeneration of the underlying resource, and within that capped amount it allocated individually permitted quotas.

Such an approach-allowing some use, while preserving the bulk (in trust terms, the res) for renewal-sets the pattern for the modern management of air and water pollution, fish and wildlife catches, the production of greenhouse gases, and nearly every other environmental problem concerning renewable resources. ${ }^{57}$ Modern environmental statutes for tradeable emission rights or individually transferrable fishing quotas reflect the basic riparian structure of limiting total use while permitting modest individual uses, even though they have vastly more sophisticated methods for allocating individual quotas and in particular for transferring individual quotas, a feature disallowed in riparian law. ${ }^{58}$

I conclude with two further observations, both concerning Sax's use of analogy and metaphor. First, I have argued elsewhere that if water instead of land were our dominant metaphor for property, we would have a quite different law of property. ${ }^{59}$ On re-reading so many of Joe Sax's articles, I think that I should have cited him for that proposition. In his work on the public trust, he has tried to educate the rest of us in the ways that water law concepts might make a difference to our attitudes about property and environmental resources. ${ }^{60}$

56. See Rose, Riparian Rights, supra note 55, at 345.

57. See id. at 345-46. See also Carol M. Rose, The Evolution of Property Rights, 3 New Palgrave Dictionary of Economics and the Law (Peter Newman, ed., 1998).

58. See, e.g., Robert W. Hahn \& Robert N. Stavins, Incentive-Based Environmental Regulation: A New Era from an Old Idea?, 18 EcologY L.Q. 1, 8-9 (1991) (describing marketable permit systems).

59. See Carol M. Rose, Property as the Keystone Right?, 71 Notre Dame L. Rev. 329,351 (1996).

60. See generally Barton H. Thompson, Jr., Water Law as a Pragmatic Exercise, 25 ECOLOGY L.Q. 363. 
The public trust doctrine by no means represents the only such water law concept-since riparian law seems at least equally significantbut it is certainly the one with the best name.

This relates to the second point: One has to suspect that the real problem with riparian law as a model for environmental management is that it has such a nondescript and uncharismatic name-quite unlike "the public trust." I have also argued elsewhere that the environmentalist case hinges not only on the physical resources that are so important and evocative in themselves, but also on the rhetorical resources that are available to us, however imperfect those may be. ${ }^{61}$ And once again, in re-reading so many of Sax's contributions, I see now that I should have cited him for that proposition as well, because of the way he highlighted and re-deployed the charismatic moniker of the "public trust." It is a tribute not only to Sax's arguments, but also to his masterful use of the rhetorical resources implicit in the name, that the "public trust in natural resources" is now so well-known and so widely referenced in our current debate on the management of natural resources.

61. See Carol M. Rose, Environmental Lessons, 27 LoY. L.A. L. REv. 1023, 1040-47 (1994); Carol M. Rose, Environmental Faust Succumbs to Temptations of Economic Mephistopheles, or, Value By Any Other Name is Preference, 87 Мich. L. REv. 1631, 1642-46 (1989) (reviewing Mark Sagoff, The Economy of the Earth (1988)). 